Gazi University
Journal of Science
http://dergipark.gov.tr/gujs

\title{
Morphology and Ultrastructure of the Nymphal Malpighian Tubules of Conocephalus fuscus fuscus (Fabricius, 1793) (Orthoptera, Tettigoniidae)
}

\author{
Irmak POLAT ${ }^{*}$ \\ Çankırı Karatekin University, Faculty of Science, Department of Biology, Çankırı, 18100, Turkey

\section{Highlights} \\ - This paper focuses on the Malpighian tubules in nymphal Conocephalus fuscus fuscus. \\ - The light microscope and transmission electron microscope techniques were used. \\ - The fine structure of the Malpighian tubules was revealed.
}

\begin{tabular}{l} 
Article Info \\
\hline \\
Received: 16 Sep 2020 \\
Accepted:18 Jan 2021 \\
Keywords \\
\hline Insect \\
Excretory system \\
Histology \\
Optical microscope \\
Transmission electron \\
microscope
\end{tabular}

\section{INTRODUCTION}

Conocephalus (Anisoptera) fuscus (Fabricius, 1793) (Orthoptera, Tettigoniidae) is a phytophagus insect and they generally feed with grasses. General distribution of this species is appears to be in Northern Africa, Kazakhstan, Iran, Pakistan, Middle Asia and a large part of Europe such as Switzerland, France, Netherlands, Germany, Bulgaria, Romania, Sweden, Spain, Italy and Turkey [1-4]. Thus, this is a widespread species. Besides, there has been some rising in global warming in recent years, which has led to the spread of this species to warmer territories Conocephalus (Anisoptera) fuscus fuscus (Fabricius, 1793) (Orthoptera, Tettigoniidae) is one of two subspecies of $C$. fuscus [1-7].

Malpighian tubules (MTs) are the main excretory organs of the classis Hexapoda (Insecta). The main roles of the MTs are the removal of the waste products, detoxification, immune defense, and thus, regulation of osmotic and ionic balance by excreting nitrogenous products and toxic compounds in terrestrial insects. Besides, they play a role in bioluminescence in some insect groups such as Arachnocampa spp. (Diptera) [8-16].

The MTs are tubular structures that have blinded end at the distal region and scattered all over the body cavity. The proximal regions of the MTs open to the midgut-hindgut junction of the digestive canal. Thus, the lumen of the MTs opens to the lumen of the hindgut [14,17-19]. 
The number of the MTs shows diversity among different insect groups. For instance, the number of the MTs can reach up to 200 in Orthoptera, while it varies from 1 to 4 in Hemiptera. Besides, the number of the MTs is 50-60 in Odonata, 6 in Lepidoptera, 12-150 in Hymenoptera, and 4 in Diptera [20,21].

The solutes and water pass into the lumen of the MTs from the hemolymph. This production of the filtrate called primary urine is ensured by active transport mechanisms. Generally, the distal segments of the MTs excrete organic solutes, water, and ions while the proximal segments of the MTs reabsorb water and useful substances and the filtrate is transferred into the lumen of the hindgut. Reabsorption continues in the rectal epithelium. Some toxic substances such as nicotine, salicylate, morphine, atropine, ouabain, etc. are the excretion products that are excreted by MTs [8,16,21-28].

In some articles studied before, structure, anatomy, and morphology of the MTs were observed in details at various insect taxon. But, the structure of nymphal MTs of $C$. fuscus fuscus was not observed. For this purpose, the nymphal MTs of $C$. fuscus fuscus were described as a means to contribute to the better comprehension of histology, anatomy, and fine structure of the excretory system of this subspecies.

\section{MATERIAL METHOD}

The nymphs of $C$. fuscus fuscus were taken from the territories along Ankara-Çankırı road and were taken to the laboratory at Gazi University, Faculty of Science, Department of Biology in June 2017. First, the MTs were dissected. Dissected specimens were firstly photographed by stereomicroscope, then, they were fixed in 5\% glutaraldehyde (phosphate-buffered, $\mathrm{pH} 7.2$ ), and were prepared for light microscope (LM) and transmission electron microscope (TEM) examinations.

\subsection{The Transmission Electron Microscopy}

Dissected samples were first rinsed in 5\% glutaraldehyde for pre-fixation and then in $1 \%$ OsO4 for postfixation. Then, the specimens were dehydrated in ethyl alcohol series (\%70, \%80,\%90,\%100) and transferred in embedding medium (Araldite) after rinsing with phosphate buffer. Subsequently, some ultrathin sections were cut from Araldite blocks and stained the sections with heavy metal salts (lead citrate, uranyl acetate) $[29,30]$. Then, the stained specimens were examined and photographed with TEM (JEOL JEM-1400) at $80 \mathrm{kV}$ acceleration voltage.

\subsection{The Light Microscopy}

For the light microscopy, some semi-thin sections were cut from Araldite blocks, put on LM slides, and then treated the sections in $1 \%$ methylene blue for staining [30]. The slides were searched with LM (Olympus BX51) and photographed.

\section{RESULTS}

In the nymphs of males and females of $C$. fuscus fuscus, there are numerous MTs that are connected to the digestive tract at the region of connection of midgut-hindgut (Figure 1). The long MTs look yellow in the stereomicroscope photographs (Figure 1). When the cross-sections of the MTs are examined, it is seen that each MT is composed of epithelial tissue with a single layer which has about 3-5 cells (Figures 2,3). That thin muscle tissue and thin connective tissue encircle the epithelial layer are sighted in TEM and LM photographs of the cross-sections of MTs (Figure 3). Besides, the trachea accompanies the MTs at the outer side of the tubules. In Figure 4, the tracheal end cell and the connection between the MT and the trachea can be seen clearly (Figure 4).

The MTs in C. fuscus fuscus have 3 types of epithelial cells. The first group of the cells outnumbers the other groups of cells and they have long microvilli at the apical side of the plasma membrane (Figure 5). In ultrathin sections of the tubule cells, it can be observed that the secretion occurs from the cytoplasm of the cells into the lumen. A large number of vesicles is also seen at the end of the microvilli (Figure 6). There are some electron-lucent vesicles and a few initial forms of the spherocrystals among the vesicles in the 
cytoplasm of the first group of epithelial cells (Figures 7,8). The basal plasma membrane of the first group of the epithelial cells has numerous short folding that extend the surface area of the basal plasma membrane (Figure 9).

The second types of cells contain cytoplasm which looks electron-dense (Figures 5, 10, 11). The microvilli at the apical side of these cells are shorter compared with those of the first group of the cells (Figure 5). The Golgi areas are abundant in the cytoplasm of these cells (Figure 11).

The cytoplasm of the third group of the epithelial cells is so electron lucent and looks as if the components of the cells were released to the lumen (Figures 5,12). The third group of the cells contains a wide range of spherocrystals with several dimensions in their cytoplasm (Figure 12).

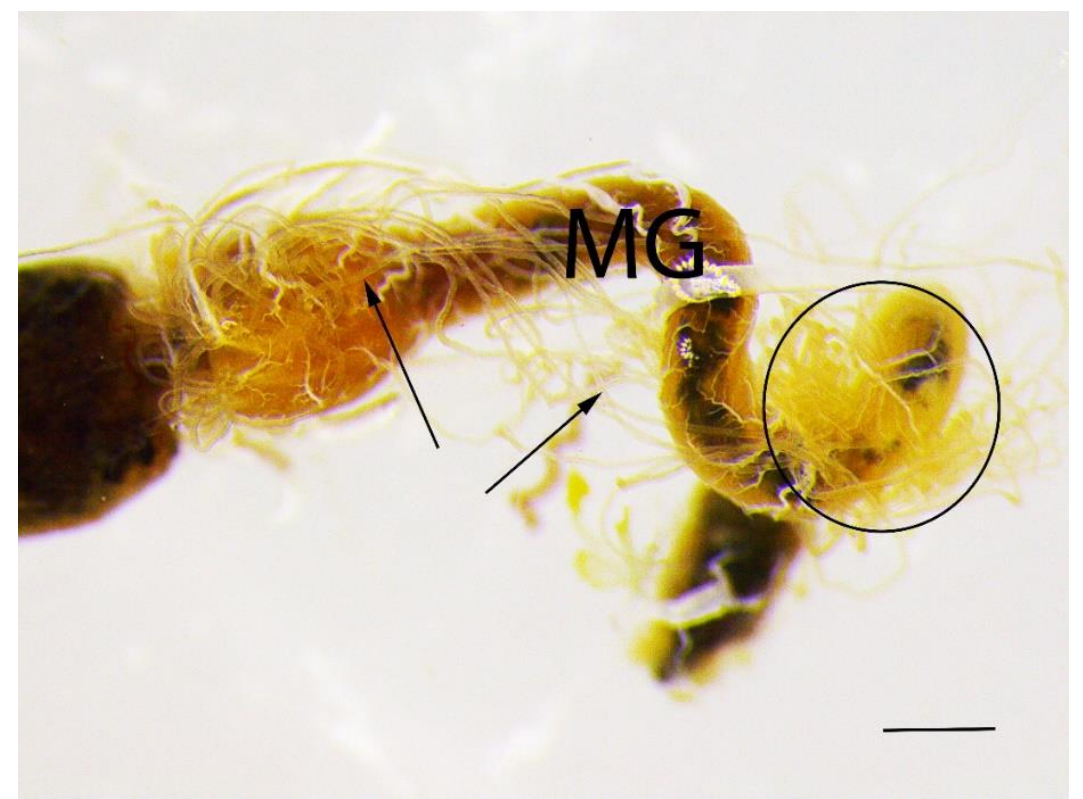

Figure 1. The general view of the midgut $(M G)$ and the MTs (arrows). The encircled part is the region where the MTs are connected to the midgut-hindgut junction (Stereomicroscope, Scale bar $=1 \mathrm{~mm}$ )

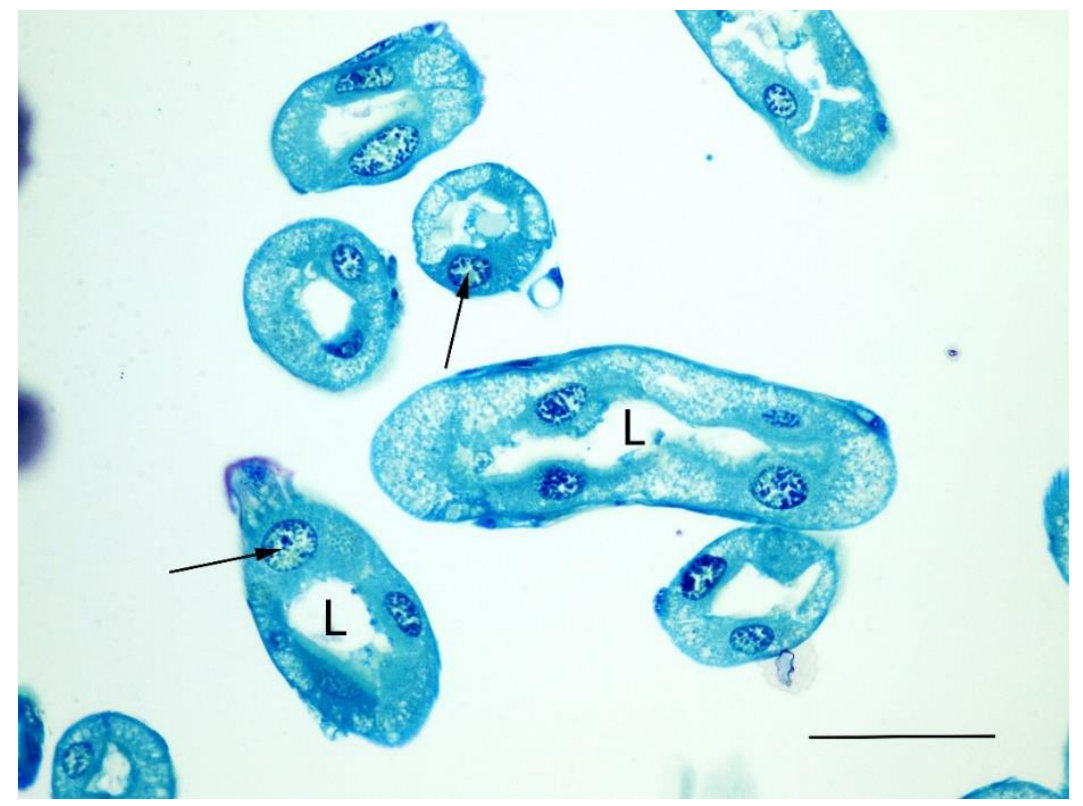

Figure 2. The semi-thin section of the MTs (arrows). L: lumen of the MTs (Light microscope, Methylene blue, $X 400$, Scale bar $=50 \mu \mathrm{m})$ 


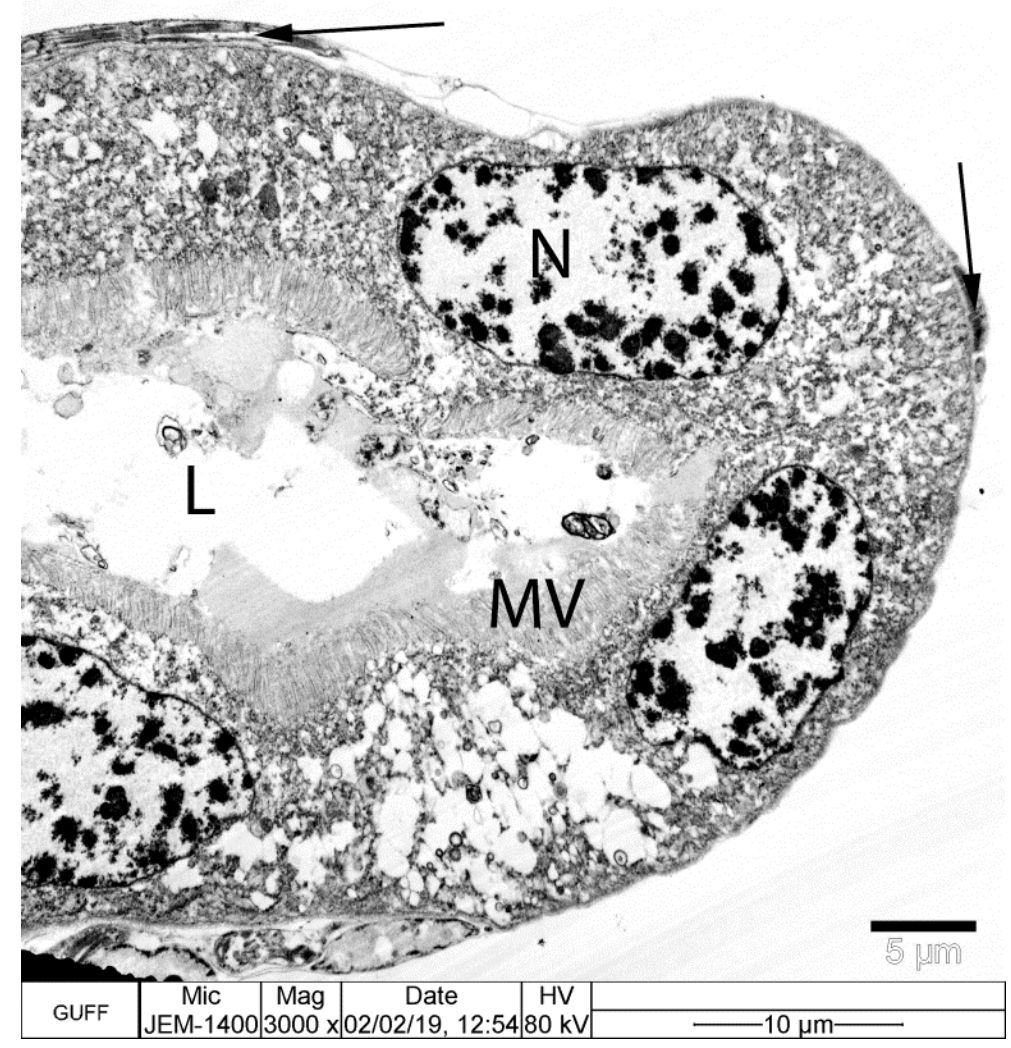

Figure 3. The thin section of the MTs. N: nucleus, L: lumen, arrows: thin muscle tissue, MV: microvilli (TEM)

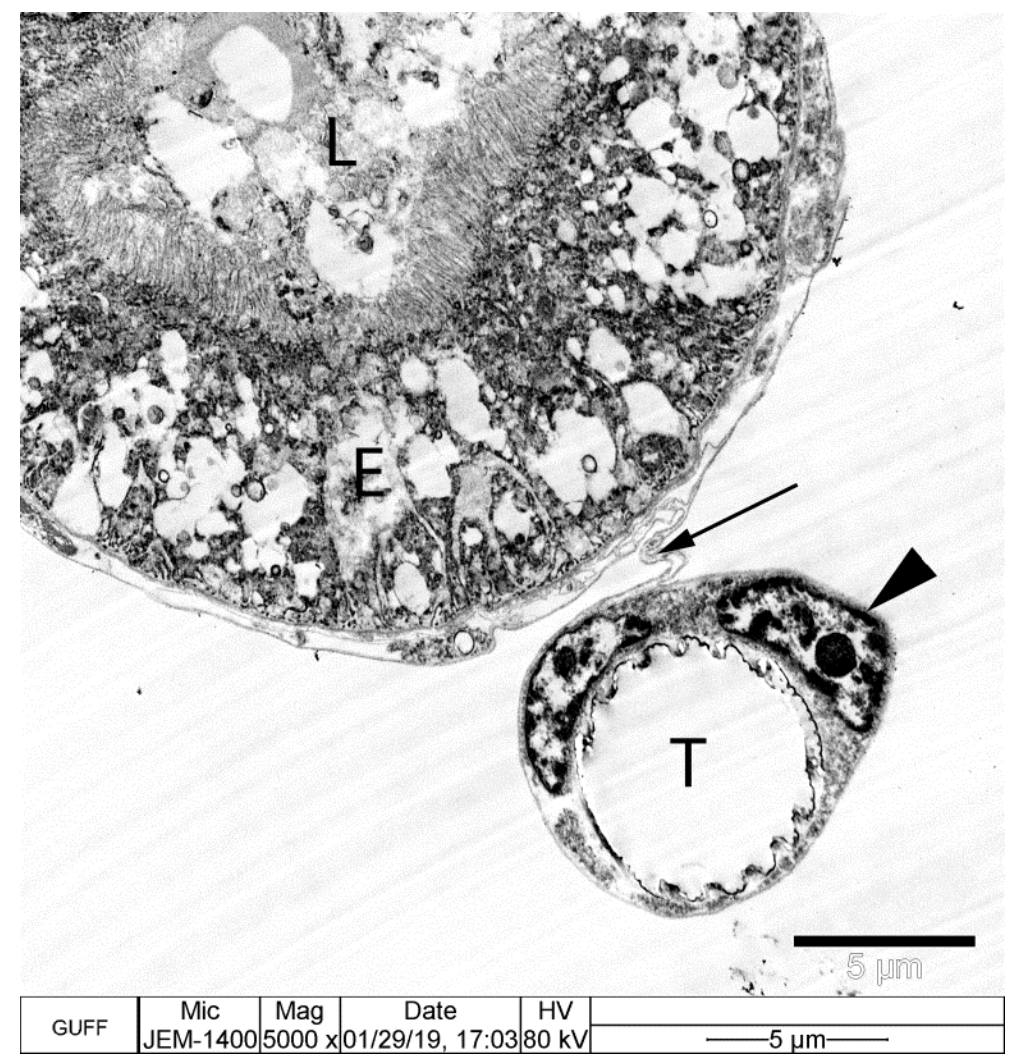

Figure 4. Connection (arrows) between MT and trachea (T). L: lumen, E: epithelium of MT, arrowhead: tracheal end cell (TEM) 


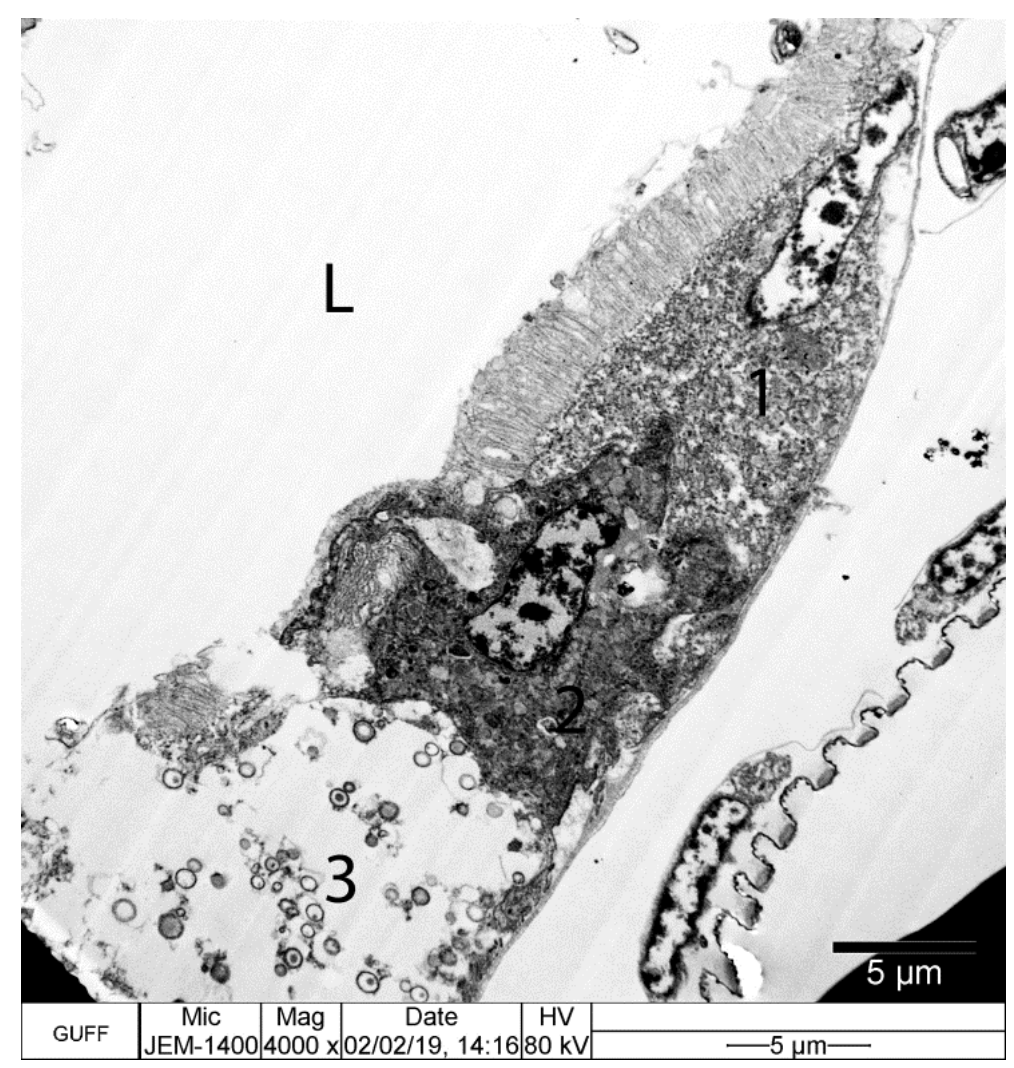

Figure 5. The longitudinal section of the MT showing all the 3 types of epithelial cells. L: lumen, 1: the first group of the epithelial cells, 2: the second group of the epithelial cells, 3: the third group of the epithelial cells (TEM)

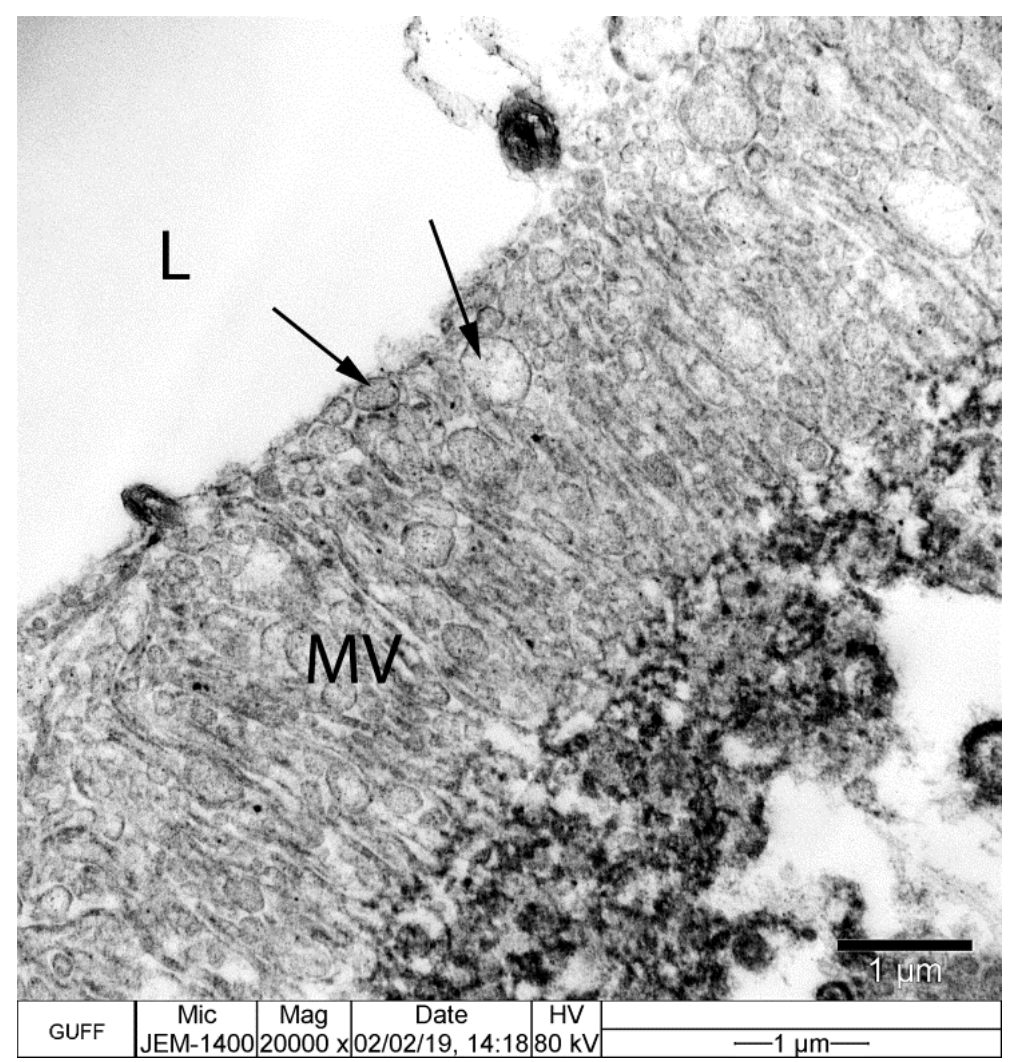

Figure 6. The secretory vesicles (arrows) among the microvilli $(M V)$ of the first group of the epithelial cells. L: lumen (TEM) 


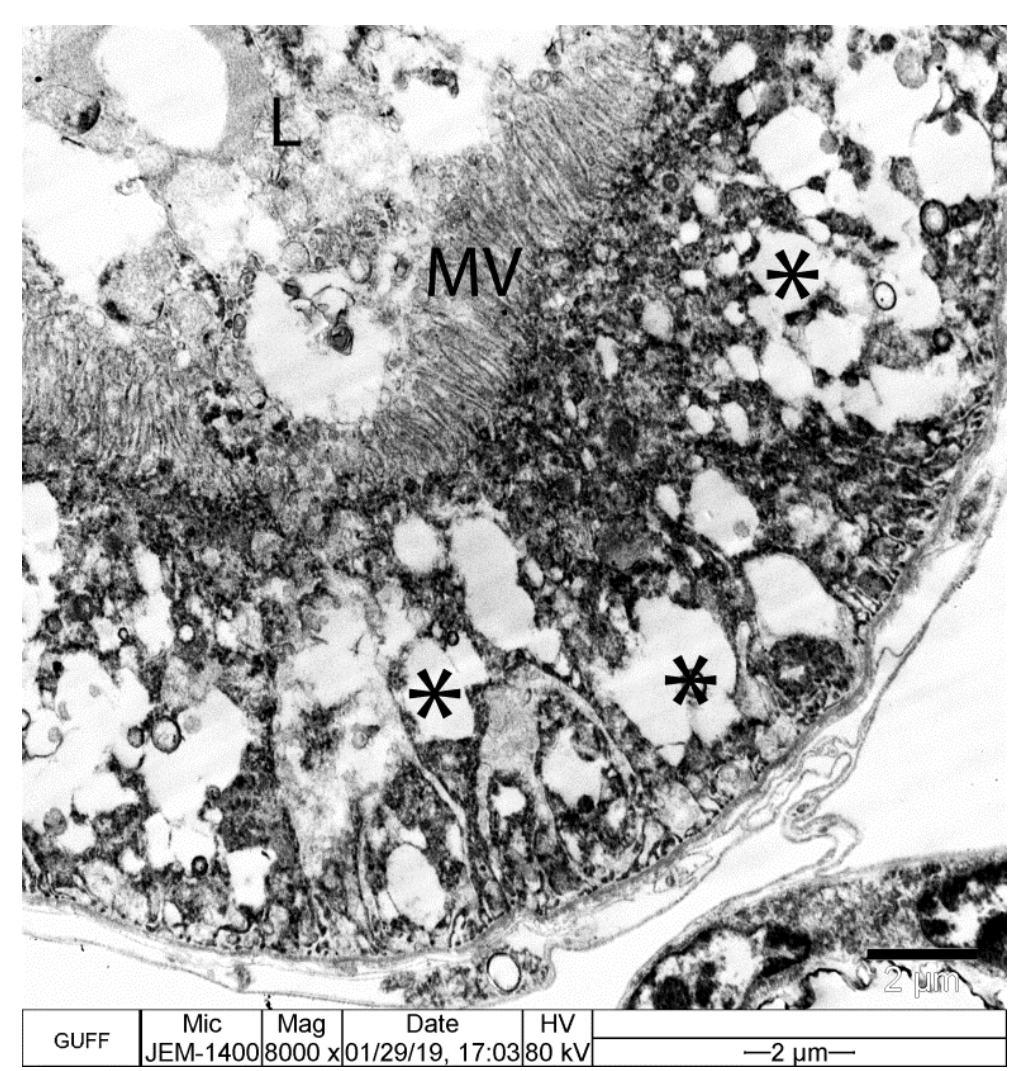

Figure 7. The cell which belongs to the first group contains electron lucent vesicles (asterisk). L: lumen, MV: microvilli (TEM)

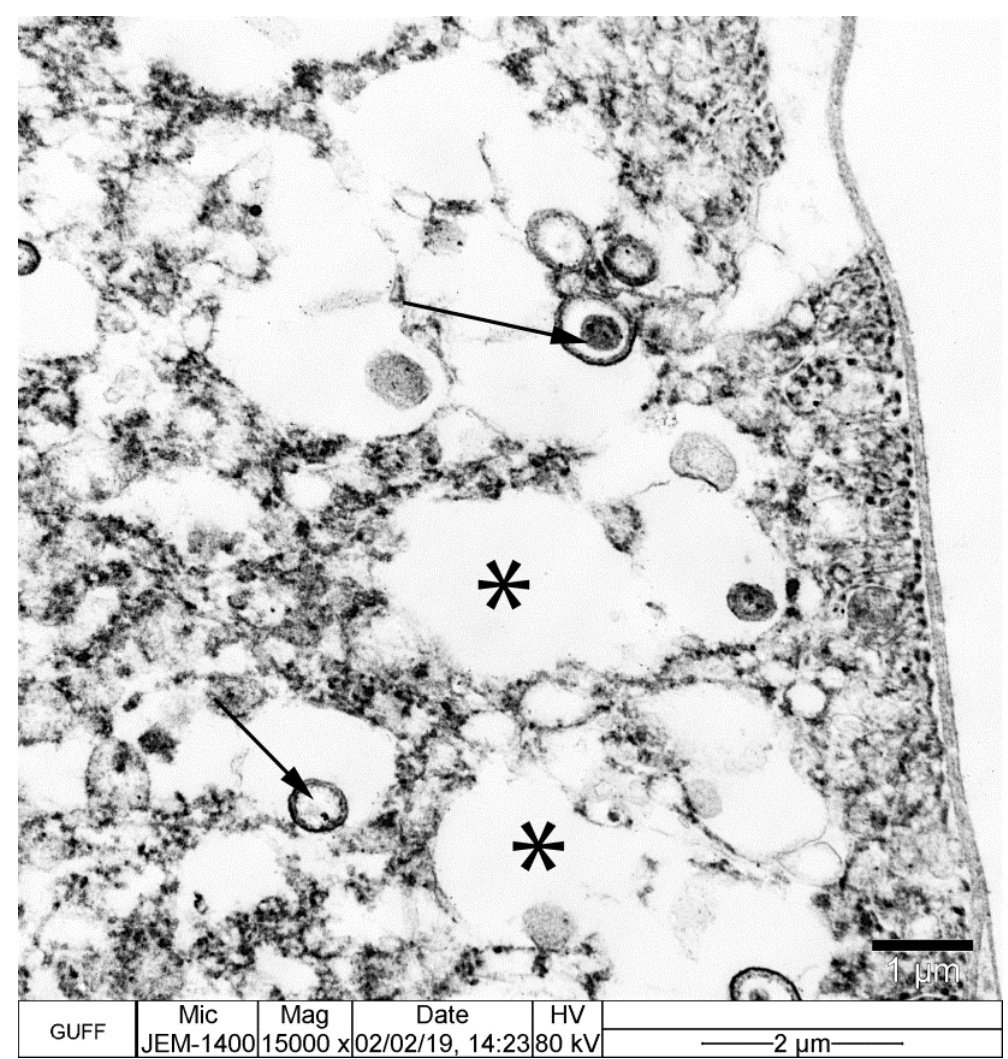

Figure 8. Electron lucent vesicles (asterisk) and some spherocrystals (arrows) among them (TEM) 


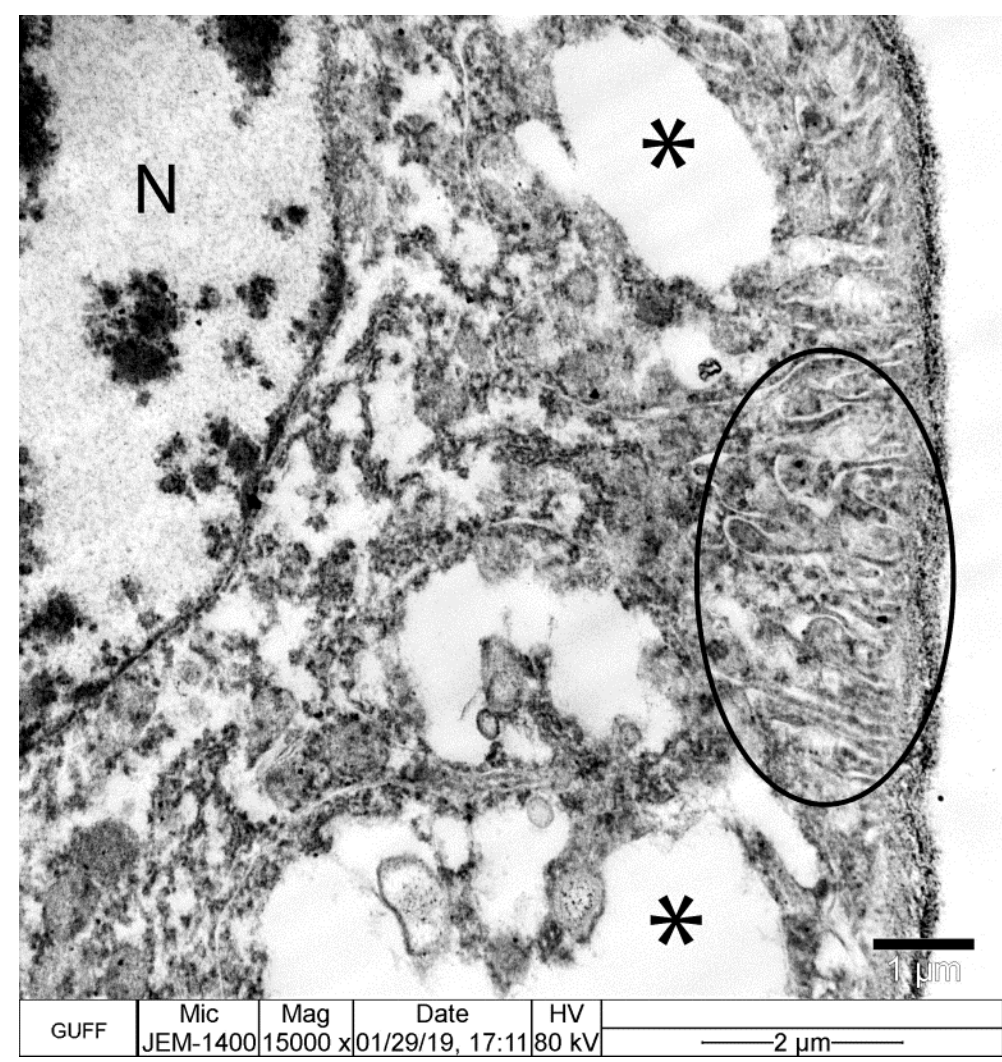

Figure 9. The basal membrane foldings (encircled) in the first group of the epithelial cells. Asterisk: electron-lucent vesicles, $N$ : nucleus (TEM)

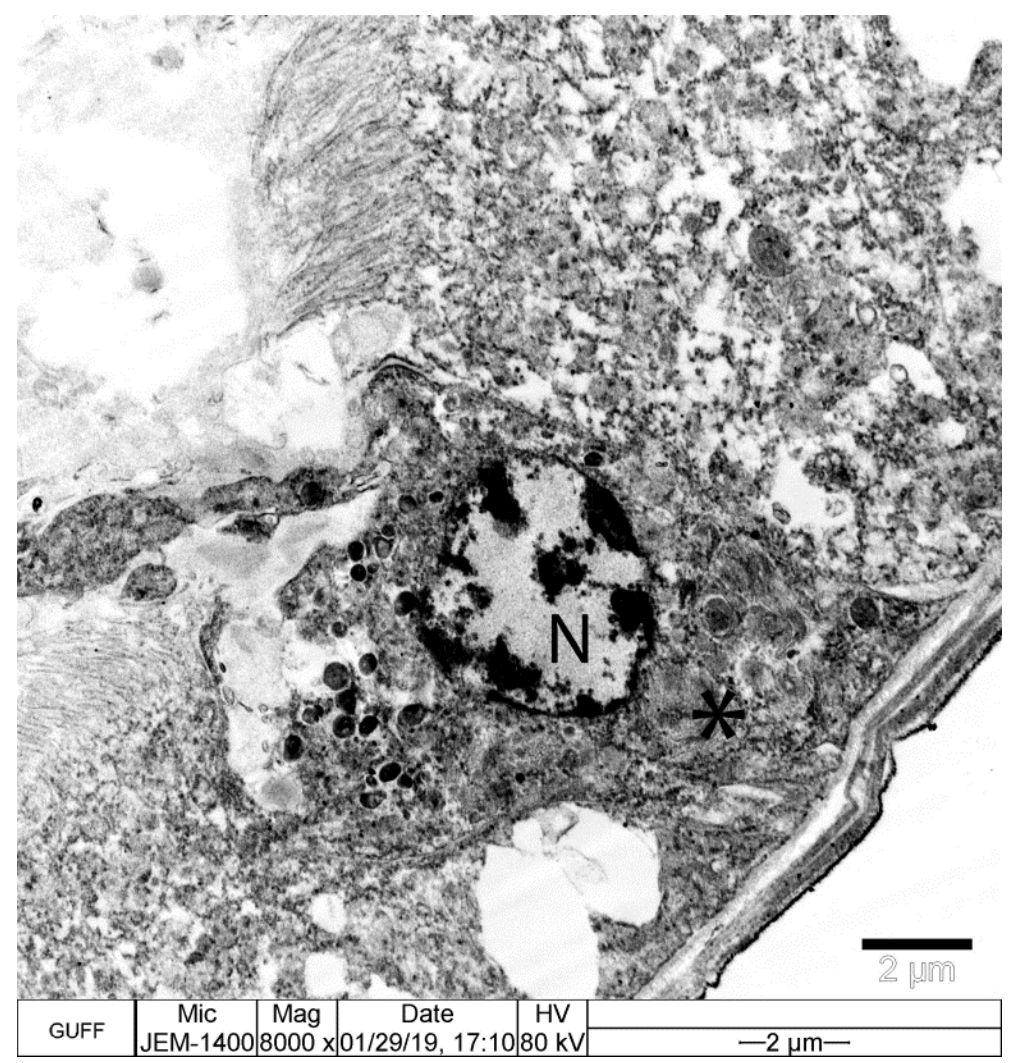

Figure 10. The second group of the epithelial cells (asterisk) with electron denser cytoplasm then the first group of the cells with round-shaped nucleus (N) (TEM) 


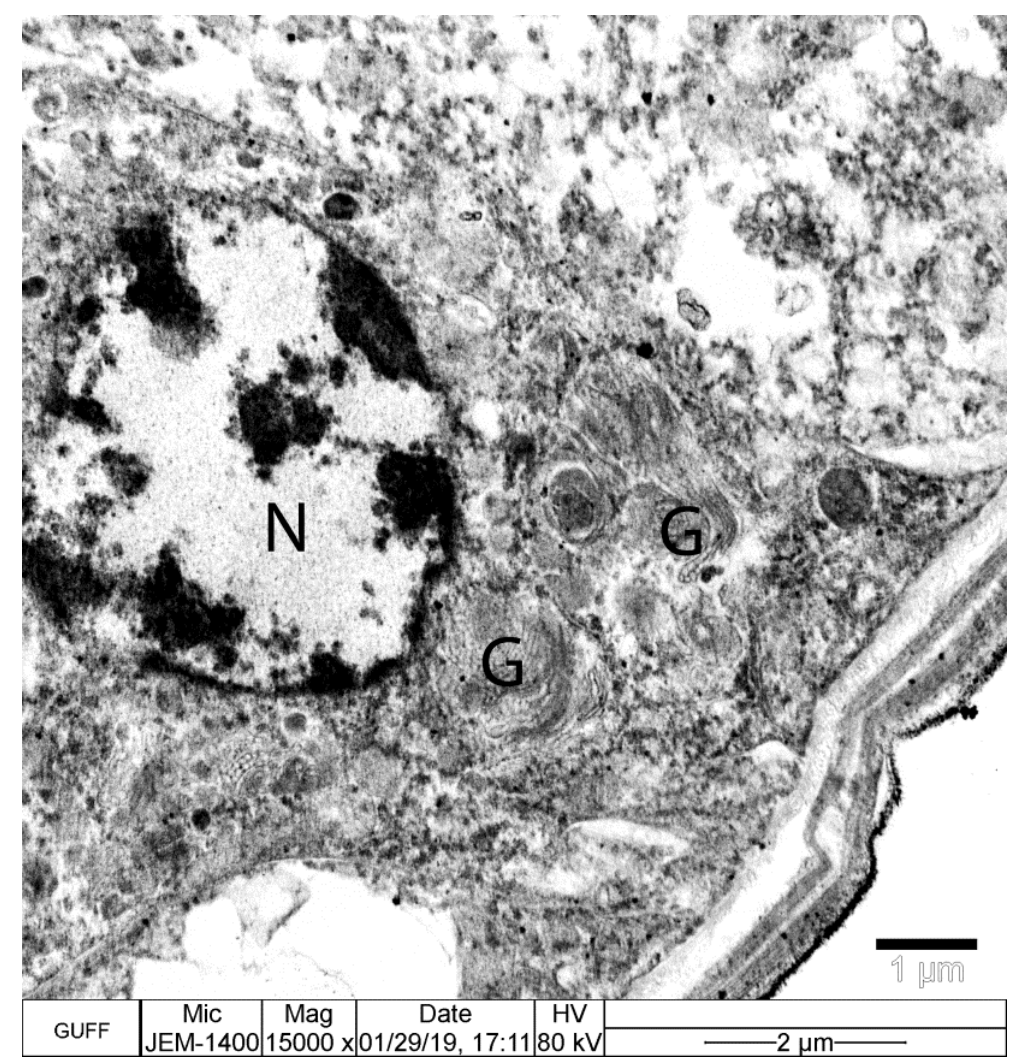

Figure 11. The Golgi areas $(G)$ in the second group of the epithelial cells. N: nucleus (TEM)

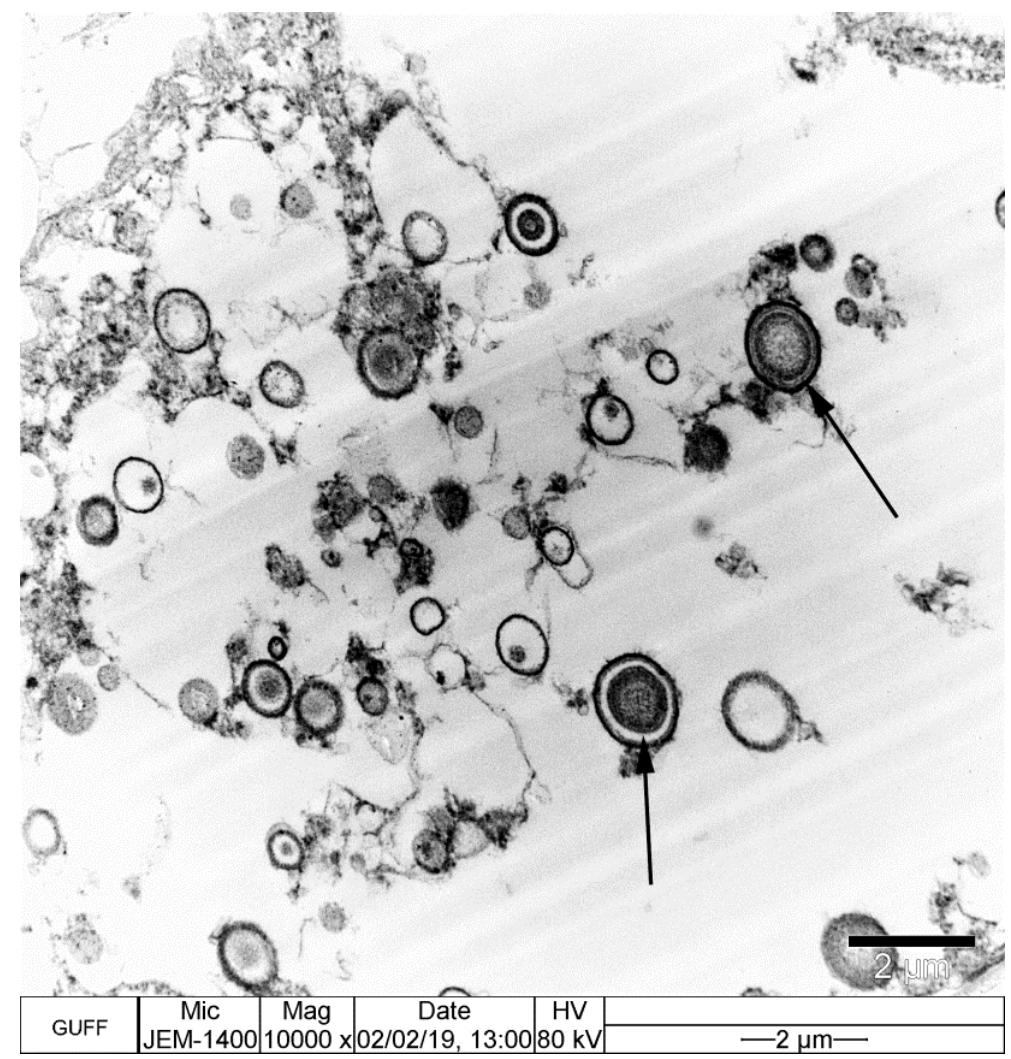

Figure 12. The spherocrystals (arrows) in the third group of the epithelial cells (TEM) 


\section{DISCUSSION}

MTs are considerably essential excretory structures of the insects. They are found on the midgut and the hindgut junction [15,31-33]. The MTs of $C$. fuscus fuscus are connected to the digestive tract through the midgut-hindgut junction as in other species. Each tubule consists of a single layer epithelium which has three or more cells. In Coboldia fuscipes (Diptera) [15], Scoliopteryx libatrix (Lepidoptera) [19] and Poecilimon cervus (Orthoptera) [30], the epithelial layer of the MTs is also monolayer.

Basal membrane folds and microvilli in the cells are considered to be indicative of active transport mechanisms [30-35]. The epithelial cells of the MTs of $C$. fuscus fuscus have numerous short basal membrane folds such as $P$. cervus (Orthoptera) [30], Troglophilus neglectus (Orthoptera) [34], Grylloblatta compodeiformis (Orthoptera) [36], and Melanoplus differentialis differentialis (Orthoptera) [37]. In C. fuscus fuscus, there are numerous long microvilli on the apical side of the epithelial cells. Similarly, in some species such as Locusta migratoria (Orthoptera) [38], Schistocerca gregaria (Orthoptera) [38], Podisus nigrispinus (Hemiptera) [39], the apical surfaces of epithelial cells have long microvilli. The mitochondria were not observed among the microvilli on the apical surface of the tubular cells of $C$. fuscus fuscus. On the other hand, mitochondria were found among the microvilli in P. cervus (Orthoptera) [30].

In C. fuscus fuscus, tubule cells contain a wide range of spherocrystals with several dimensions. Spherocrystals provide the accumulation of minerals and organic materials necessary for cells and also has the task of depositing toxic metals and regulating the mineral composition. There are numerous spherocrystals in the tubule cells of P. cervus [30] and T. neglectus [34], which are an Orthoptera species and Terrobittacus implicates (Mecoptera) [40].

In ultrathin sections of the tubule cells in C. fuscus fuscus, it was observed that the secretion occurs from the cytoplasm of the cells into the lumen. A large number of vesicles were also seen at the end of the microvilli. This result showed that the waste materials will be transferred from the tubule lumen to the hindgut or useful materials are carried into the hemolymph $[41,42]$.

In conclusion, although the general structure and morphology of MTs of C. fuscus fuscus has some differences with the insects of Orthoptera or other orders, its histological and ultrastructural structure are very similar. This is because the task of MTs is similar in all insect groups.

\section{ACKNOWLEDGEMENT}

We express our gratitude to Prof. Dr. Mustafa ÜNAL (Bolu Abant İzzet Baysal University) for getting the diagnosis of the subspecies (Conocephalus fuscus fuscus).

\section{CONFLICTS OF INTEREST}

No conflict of interest was declared by the author.

\section{REFERENCES}

[1] Ragge, D. R. Grasshoppers, Crickets and Cockroaches of the British Isles, F Warne and Co, London, (1965).

[2] Budrys, E., Našlènienè, A., Winkler, C., "First records of Conocephalus fuscus and Omocestus rufipes (Orthoptera: Conocephalidae, Acrididae) in Lithuania", New and Rare for Lithuania Insect Species, 27: 12-14, (2015).

[3] Sadiq, S., Panhwar, W. A., Sultana, R., Saeed, M., Wagan, S. A., Ahmed, S., "New record of Conocephalus (Anisoptera) fuscus (Fabricius, 1793) (Conocephalinae: Tettigoniidae: Orthoptera) from Pakistan", Journal of Entomology and Zoology Studies, 5(3): 1431-1434, (2017). 
[4] Ruchin, A. B., Mikhailenko, A. P., "Fauna of mantids and orthopterans (Insecta: Mantodea, Orthoptera) of the Mordovia State Nature Reserve, Russia", Biodiversitas Journal of Biological Diversity, 19(4): 1194-1206, (2018).

[5] Ramme, W., "Zur Systematik, Faunistik und Biologie der Orthopteren von Südost-Europa und Vorderasien", Mitteilungen aus dem Zoologischen Museum in Berlin, 27: 1-421, (1951).

[6] Ünal, M., "Tettigoniidae (Orthoptera) from Turkey and the Middle East", Transactions of the American Entomological Society, 132(1): 157-203. (2006).

[7] Ünal, M., "Tettigoniidae (Orthoptera) from Turkey and the Middle East II", Transactions of the American Entomological Society, 138(1-2): 21-54, (2012).

[8] Arab, A., Caetano, F. H., "Segmental specializations in the Malpighian tubules of the fire ant Solenopsis saevissima Forel 1904 (Myrmicinae): an electron microscopical study", Arthropod Structure and Development, 30: 281-292, (2002).

[9] Rakitov, R. A., "Structure and function of the Malpighian tubules, and related behaviors in juvenile Cicadas: Evidence of homology with Spittlebugs (Hemiptera: Cicadoidea and Cercopoidea)", Zoologischer Anzeiger- A Journal of Comparative Zoology, 241: 117-130, (2002).

[10] Cordeiro, B. A., Tibúrcio, V. H. S., Hallwass, M., Paes, H. C., Ribeiro, B. M., Báo, S. N., "Structural and ultrastructural alterations of Malpighian tubules of Anticarsia gemmatalis (Hübner) (Lepidoptera: Noctuidae) larvae infected with different Anticarsia gemmatalis multiple nucleopolyhedrovirus (AgMNPV) recombinant viruses", Journal of Invertebrate Pathology, 98: 7-19, (2008).

[11] Dow, J. A. T., "Insights into the Malpighian tubule from functional genomics", Journal of Experimental Biology, 212: 435-445, (2009).

[12] Wu, G. X., Gao, X., Ye, G. Y., Li, K., Hu, C., Cheng, J. A., "Ultrastructural alterations in midgut and Malpighian tubules of Boettcherisca peregrina exposure to cadmium and copper", Ecotoxicology and Environmental Safety, 72: 1137-1147, (2009).

[13] King, B., Denholm, B., "Malpighian tubule development in the red flour beetle (Tribolium castaneum)", Arthropod Structure and Development, 43: 605-613, (2014).

[14] Zhong, H., Zhang, Y., Wei, C., "Morphology and ultrastructure of the Malpighian tubules in Kolla paulula (Hemiptera: Cicadellidae)", Zoologischer Anzeiger- A Journal of Comparative Zoology, 257: 22-28, (2015).

[15] Giglio, A., Perrotta, I. D., Brandmayr, P., "Exosomes: Ultrastructural evidence in epithelial cells of Malpighian tubules", Micron, 100: 34-37, (2017).

[16] Silva, J. R., Amaral, D. T., Viviani, V. R., "Comparison of the Malpighian tubules and fat body transcriptional profiles of Zophobas morio larvae (Coleoptera: Tenebrionidae)", Comparative Biochemistry and Physiology Part D Genomics and Proteomics, 29: 95-105, (2019).

[17] Roeder, K. D., College, T., Insect Physiology, London, UK: Chapman\&Hall Ltd., (1953).

[18] Martini, S. V., Nascimento, S. B., Morales, M. M., "Rhodnius prolixus Malpighian tubules and control of diuresis by neurohormones", Anais da Academia Brasileira de Ciências, 79(1): 87-95, (2007). 
[19] Lipovšek, S., Janžekovič, F., Novak, T., "Ultrastructure of fat body cells and Malpighian tubule cells in overwintering Scoliopteryx libatrix (Noctuoidea)", Protoplasma, 254: 2189-2199, (2017).

[20] Denholm, B., Skaer, H., Development of the Malpighian Tubules in Insects, Cambridge, UK: University of Cambridge, (2005).

[21] Pacheco, C. A., Alevi, K. C. C., Ravazi, A., Oliveira, M. T. V. A., "Malpighian tubule, an essential organ for insects," Entomology, Ornithology and Herpetology, 3(122), (2014). DOI: 10.4172/2161-0983.1000122

[22] Maddrell, S. H. P., Gardiner, B. O. C., "The passive permeability of insect Malpighian tubules to organic solutes", Journal of Experimental Biology, 60: 641-652, (1974).

[23] Maddrell, S. H., Gardiner, B. O., "Excretion of alkaloids by Malpighian tubules of insects", Journal of Experimental Biology, 64(2): 267-281, (1976).

[24] Maddrell, S. H. P., "The functional design of the insect excretory system", Journal of Experimental Biology, 90: 1-15, (1981).

[25] Gaertner, L. S., Murray, C. L., Morris, C. E., "Transepithelial transport of nicotine and vinblastine in isolated Malpighian tubules of the tobacco hornworm (Manduca sexta) suggests a Pglycoprotein-like mechanism", Journal of Experimental Biology, 201(18): 2637-2645, (1998).

[26] Torrie, L. S., Radford, J. C., Southall, T. D., Kean, L., Dinsmore, A. J., Davies, S. A., Dow, J. A., "Resolution of the insect ouabain paradox", Proceedings of the National Academy of Sciences, 101(37): 13689-13693, (2004).

[27] Ruiz-Sanchez, E., Van Walderveen, M. C., Livingston, A., O’Donnell, M. J., "Transepithelial transport of salicylate by the Malpighian tubules of insects from different orders", Journal of Insect Physiology, 53(10): 1034-1045, (2007).

[28] Gautam, N. K., Tapadia, M. G., "Overview of Malpighian tubules development and function in Drosophila melanogaster", Journal of Scientific Research, 58: 87-98, (2014).

[29] Amutkan Mutlu, D., Suludere, Z., "Ultrastructure of the proventriculus in adult Isophya nervosa (Orthoptera: Tettigoniidae)", Munis Entomology and Zoology Journal, 15(2): 647-654.

[30] Polat, I., "The ultrastructural features of the digestive, excretory, female and male reproductive systems of Poecilimon cervus Karabag, 1950", Phd. thesis, Gazi University Institution of Science, Ankara, 1-187, (2016).

[31] Hazelton, S. R., Felgenhauer, B. E., Spring, J. H., "Ultrastructural changes in the Malpighian tubules of the house cricket, Acheta domesticus, at the onset of diuresis: a time study", Journal of Morphology, 247(1): 80-92, (2001).

[32] Gillott, C., Entomology, The Netherlands: Springer Science \& Business Media (2005).

[33] Nocelli, R., Cintra-Socolowski, P., Roat, T., Silva-Zacarin, E., Malaspina, O., "Comparative physiology of Malpighian tubules: form and function", Insect Physiology, 2016(6): 13-23, (2016).

[34] Delakorda, S. L., Letofsky-Papst, I., Novak, T., Hofer, F., Pabst, M.A., "Structure of the Malpighian tubule cells and annual changes in the structure and chemical composition of their spherites in the cave cricket Troglophilus neglectus Krauss, 1878 (Raphidophoridae, Saltatoria)", Arthropod Structure and Development, 38: 315-327, (2009). 
[35] Pal, R., Kumar, K., "Ultrastructural features of the larval Malpighian tubules of the flesh fly Sarcophaga ruficornis (Diptera: Sarcophagidae)", International Journal of Tropical Insect Science, 32(3): 166-172, (2012).

[36] Jarial, M.S., "Fine structure of Malpighian tubules Grylloblatta compodeiformis (Orthoptera: Grylloblattidae)", Transactions of the American Microscopical Society, 109(4): 329-341, (1990).

[37] Beams, H. W., Tahmisian, T. N., Devine, R. L., "Electron microscope studies on the cells of the Malpighian tubules of the grasshopper (Orthoptera, Acrididae)", The Journal of Biophysical and Biochemical Cytology, 1(3): 197-212, (1955).

[38] Prado, M. A., Montuenga, L. M., Villaro, A. C., Etayo, J. C., Polak, J. M., Sesma, M. P., “A novel granular cell type of locust malpighian tubules: Ultrastructural and immunocytochemical study", Cell and Tissue Research, 268(1): 123-130, (1992).

[39] Da Cunha, F. M., Caetano, F. H., Wanderley-Teixeira, V., Torres, J. B., Teixeira, A. A., Alves, L. C., "Ultra-structure and histochemistry of digestive cells of Podisus nigrispinus (Hemiptera: Pentatomidae) fed with prey reared on bt-cotton”, Micron, 43(2): 245-250, (2012).

[40] Liu, L., Hua, B. Z., "Ultrastructure of the larval Malpighian tubules in Terrobittacus implicatus (Mecoptera: Bittacidae)" Protoplasma, 255(4): 1121-1128, (2018).

[41] Berridge, M. J., Oschman, J. L., "A structural basis for fluid secretion by Malpighian tubules", Tissue Cell, 1(2): 247-272, (1969).

[42] Ruiz-Sanchez, E., O'Donnell, M. J., Donini, A., "Secretion of $\mathrm{Na}+$, K+ and fluid by the Malpighian (renal) tubule of the larval cabbage looper Trichoplusia ni (Lepidoptera: Noctuidae)", Journal of Insect Physiology, 82: 92-98, (2015). 